\title{
TERORISME DITINJAU DARI PERSPEKTIF HUKUM PIDANA ISLAM (FIQIH JINAYAH)
}

\author{
Zulkifli, Muh. Syarif Hasyim, Hamiyuddin
}

\begin{abstract}
The discussion in this research is terrorism from the perspective of Islamic criminal law (fiqih jinayah). The problem that becomes the focus of research is how terrorism is in the review of Islamic criminal law or jinnayah figh. Qualitative research, the source of which is library research, is the method used in research. There are two kinds of data sources in this research, namely primary and secondary data sources, while the data collection and analysis uses literature review research. The data were analyzed using the Islamic criminal law theory approach. So as a result of this research that acts of terrorism are not justified in Islamic teachings. The birth of this action is because the perpetrators have shallow thoughts or have very minimal thoughts and have political goals to harm themselves and others. They even consider this act as Jihad, even though in fact it is not a jihad but an act that brings fear to potential victims.
\end{abstract}

Keywords: Islamic criminal law (fiqih jinayah), Terrorism, Jihad 


\section{A. Pendahuluan}

Terorisme sudah menjadi berita yang hangat dibicarakan dalam media massa dan elektronik. Kejahatan terorisme telah melampaui batas yang mengorbankan nyawa orang yang tidak bersalah, ini disebabkan karena pelakunya memiliki paham radikalisme dan ingin mencapai tujuan politik. Oleh Karena itu, Pemerintah dan masyarakat bersama-sama ikut andil untuk mencegah dan memberantas terorisme. Dan terorisme merupakan tindak kejahatan asusila yang tidak berperikemanusiaan. ${ }^{1}$

Kejahatan tersebut harus dicegah dan diberantas, karena terorisme merupakan tindakan yang merugikan. Dan tindakan mereka ini sama halnya dengan pembunuhan disengaja. Pembunuhan disengaja yaitu pembunuhan yang diniati oleh si pelaku. Sebagai contoh si pelaku memukul korbannya dengan alat yang bisa mematikan. ${ }^{2}$ Sesuai dengan firman Allah swt. yaitu Q.S. Al-Maidah [5] : 45.

Terjemahnya:

Dan Kami telah tetapkan terhadap mereka di dalamnya (At Taurat) bahwasanya jiwa (dibalas) dengan jiwa,...

Kejahatan terorisme telah meresahkan masyarakat. Ini semua dikarenakan pengeboman yang dilakukan oleh para teroris, akibatnya ekonomi suatu negara mengalami krisis. Di samping itu, kestabilan sosial di suatu negara mulai terancam.

\section{Juli 2018)}

${ }^{1}$ luax-berjaya-blogspot.com/2011/10/kejahatan-terorisme.html. (Diakses 23

${ }^{2}$ Muh. Amin Suma \& Dkk., Pidana Islam Di Indonesia Peluang, Prospek, dan Tantangan, Cet I, (Pejaten Barat: Pustaka Firdaus, 2001), 94.

${ }^{3}$ Al-Qur'an dan Terjemahannya (Mushaf Fatimah), (Jakarta: PT. Insan Media Pustaka, 2012), 115. 
Terorisme ada diberbagai negara, karena dipengaruhui oleh beberapa faktor, di anataranya perluasan transportasi udara, adanya kesamaan ideologi merupakan penyebab meluasnya aksi terorisme di seluruh dunia. Coverage televisi telah berperan untuk memperluas jaringan terorisme dengan cara menjangkau lebih banyak liputan tentang terorisme. ${ }^{4}$

Kejahatan terorisme yang berkembang dan menyebabkan peristiwa pembunuhan massal mengakibatkan eksistensi dan kesuciannya HAM telah hilang, dikarenakan tindakan terorisme yang telah menciptakan perbuatan yang tidak manusiawi. ${ }^{5}$

Pandangan Islam mengenai tindakan terorisne, tidak sama sekali membenarkan menyebarkan risalah agama dengan kekerasan dan menakut-nakuti masyarakat dengan tindakan yang tidak sepantasnya untuk dilakukan. Orang yang membunuh dan mengambil harta bendanya dengan cara kekerasan atau bom bunuh diri, itu tidak dibenarkan dalam agama Islam. ${ }^{6}$ Tetapi, yang sekarang banyak persepsi bahwa kejahatan terorisme dikaitkan dengan islam padahal sebenarnya islam tidak seperti itu. Islam sebenarnya adalah agama yang damai, agama rahmatan lil 'ālaminn. Jika ada orang mengaitkan islam dengan terorisme, maka itu bertentangan dengan sejarah. ${ }^{7}$

Penelitian pustaka (library research) merupakan penelitian yang datanya bersumber dalam buku referensi sebagai jenis penelitian yang digunakan. Metode yang digunakan adalah metode penelitian kualitatif. Penelitian kualitatif adalah penelitian yang penemuan-

${ }^{4}$ Budi Winarno, Dinamika Isu-Isu Global Kontemporer, (Yogyakarta : Center of Academic Publishing Service (CAPS), Buku Seru, 2014). 177-178.

${ }^{5}$ Mardenis, Pemberantasan Terorisme, Politik Internasional dan Politik Hukum Nasional Indonesia, (Jakarta : Raja Grafindo Persada, 2011). 119.

${ }^{6}$ Muhammad Hanif Hassan, Teroris Membajak Islam, Meluruskan Jihad Sesat Imam Samudra \& Kelompok Islam Radikal, (Jakarta Selatan : Grafindo Khazanah Ilmu, 2007). 262.

${ }^{7}$ Muh. Chirzin, Reaktualisasi Jihad fi Sabilillah dalam Konteks Kekinian dan Keindonesiaan, Ulumuna, Volume X, Nomor 1 Januari-Juni 2006. 
penemuannya tidak dapat dicapai dengan adanya prosedur-prosedur statistik atau cara-cara kuantifikasi. ${ }^{8}$

Seperti uraian latar belakang di atas, penelitian akan memfokuskan dalam penjelasan dan pemahaman terhadap permasalahan yang ada seperti apa perbedaan terorisme dengan jihad, bagaimana tinjauan hukum pidana Islam mengenai terorisme dan mengapa terorisme dikaitkan dengan jihad.

\section{B. Perbedaan Terorisme dengan Jihad}

Ada beberapa perbedaan antara terorisme dan jihad yaitu:

a. Perbedaan pertama

Para mujahid berjihad di jalan Allah dengan izin waliyul amr/pemerintah karena jihad sudah menjadi bagian dari perjanjian milik pemerintah. Sedangkan teroris, mereka tidak mau minta izin kepada pemerintahnya untuk berperang, karena mereka tidak mau berjihad dengan syar'i, yang mereka inginkan ialah kekacauan dan fitnah-fitnah serta penumpahan darah. Bahkan teroris telah mengklaim waliyul amr/pemerintah muslimin sebagai orang kafir dan memeranginya.

b. Perbedaan Kedua

Sebelum berangkat perang, para mujahid meminta izin kepada kedua orang tuanya dalam selain berjihad fardhu 'ain. Karena Nabi saw perintah kepada para sahabat untuk kembali pada kedua orang tuanya karena mereka saat berangkat perang tidak minta izin kepada kedua orang tua. Sedangkan teroris tidak pernah meminta izin kepada kedua orang tuanya disebabkan dia tahu bahwa apa yang dia lakukan itu tidak diterima oleh seorangpun apalagi kedua orang tuanya. Dan dia tidak suka terbuka dengan orang lain sampai kegiatannya itu harus dirahasiakan sekalipun orang yang dekat dengannya. Dan bukan hanya tidak meminta izin dan juga mereka berdusta kepada kedua orang tuanya.

c. Perbedaan Ketiga

Mujahid berperang kepada orang kafir dan musyrik atas dasar firman Allah swt. Q.S. At Taubah (9) : 123.

${ }^{8}$ Djunaidi Ghony \& Fauzan Almanshur, Metodologi Penelitian Kualitatif, (Yogyakarta : Ar-Ruzz Media, 2016) 25. 


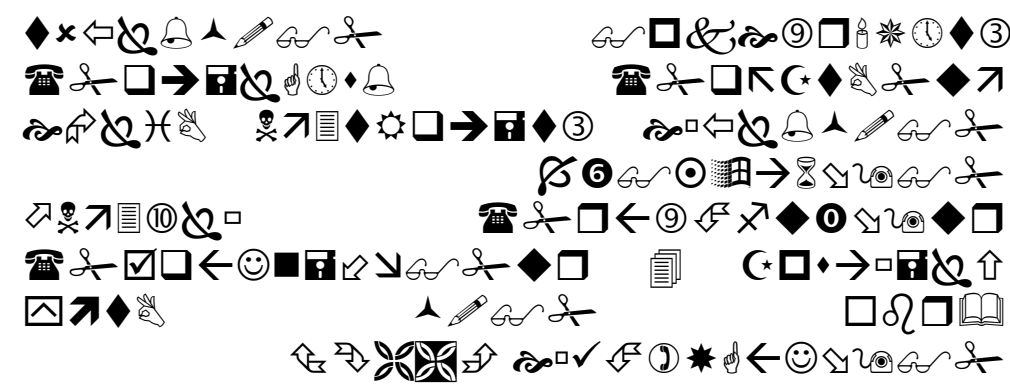

Terjemahnya:

Hai orang-orang yang beriman, perangilah orangorang kafir yang di sekitar kamu itu, dan hendaklah mereka menemui kekerasan daripadamu, dan ketahuilah, bahwasanya Allah bersama orang-orang yang bertaqwa. ${ }^{9}$

Adapun teroris mereka telah berperang kepada orang muslim sebagaimana Nabi saw bersabda tentang mereka (mereka memerangi ahlul Islam dan membiarkan penyembah berhala) oleh karena itu, mereka juga telah membunuh para polisi petugas keamanan dan melakukan pengeboman di masjid dan membunuh orang yang bertauhid dan orang- yang melakukan shalat padahal Nabi saw. bersabda (saya melarang dari membunuh para orang yang shalat).

d. Perbedaan Keempat

Mujahid menjaga keamanan dan keselamatan negerinya. Sedangkan teroris mereka merusak keamanan di negeri muslim dan menimbulkan rasa takut dan ngeri kepada masyarakat setempat.

e. Perbedaan Kelima

Mujahid telah mengambil fatwa dan hukum jihadnya dari sumber yang dipercaya yaitu kitab Al-Quran dan sunnah, beserta aqidah, fiqih, dan mengambil fatwa tersebut dari Samahat Mufti (Ketua Dewan Fatwa) dan Samahat Syaikh Al-Fauzan serta dari Lajnah Daimah lil Ifta (Lembaga Tetap Dewan Fatwa) dan dari Haiah Kibaril 'Ulama (Badan Ulama Besar). Adapun teroris yang tidak memperhatikan syariat agama, dan tidak memperhatikan halal dan haram, dan sejatinya mereka tidak peduli kepada siapa mereka mengambil fatwa, yang penting itu sesuai dengan hawa nafsunya, dan oleh sebab itu kita melihat mereka mengambil fatwa dari pemuda

${ }^{9}$ Ibid, 207. 
kecil seperti mereka, dan mencari hukum kepada orang bodoh seperti mereka dan mengambil fatwa dari orang yang tidak dikenal dan juga majhul. ${ }^{10}$

\section{Ketidakterkaitan Antara Terorisme dan Jihad}

Menurut Musdar jihad itu harus dilakukan sesuai dengan aturan-aturan islam dan amar ma'ruf nahi munkar, Islam tidak pernah mengajarkan kekerasan yang tidak terarah yang berdampak pada kebencian. Jihad itu harus mempunyai manfaat separti menakut-nakuti orang-orang kafir dan menjatuhkan mentalnya. ${ }^{11}$

Di Indonesia, para teroris memiliki ketua yang bernama Nurdin M Top dan memiliki hubungan dengan Al-Qaedah selaku gerakan teroris internasional. Ledakan sering terjadi di negara kita ini dan terakhir terjadi di hotel JW Marriot yaitu tanggal 17 Juli 2009. Bagi kepahamannya masih kurang mengenai agama mungkin mereka dianggap para mujahidin yang kematiannya dengan cara bom bunuh diri itu membawanya ke surganya Allah dengan status mati syahid.

Inilah hukum yang Allah berikan kepada kaum bani israil, yaitu kaum yang menyukai pembunuhan. Ayat tersebut tidak terkecuali kepada kaum bani israil saja, tapi untuk seluruh umat. Hanya saja Allah menghubungkan ayat ini kepada kaum bani israil, karena mereka suka membunuh manusia, sampai para Nabi-Nabi pun telah dibunuh oleh mereka.

Menzhalimi orang apalagi sampai membunuhnya ialah perbuatan yang diharamkan oleh Allah dan Rasul-Nya. Perbuatan seperti ini ialah pembunuhan di sengaja dan termasuk perbuatan keji yang mengancam ketenteraman umum, maka manusia tidak semenamena melakukannya karena Allah akan memberikan balasan yang setimpal, yaitu hukuman berat di dunia dan mendapat azab yang berat

\footnotetext{
${ }^{10} \mathrm{http} / /$ www.ahlussunnahponorogo.id/2017/01/perbedaan-antara-jihad-danterorisme. html

${ }^{11}$ Saidurrahman, Fiqh Jihad dan Terorisme (Perspektif Tokoh Ormas Islam Sumatera Utara), Jurnal Ilmu Syariah dan Hukum, Vol. 46 No. 1. Januari-Juni 2012.
} 
di akhirat kelak. ${ }^{12}$ Bukan seperti pemahaman mereka bahwa seluruh orang kafir itu halal darahnya untuk dibunuh. Tindakan tersebut ialah kedangkalan akal mereka.

Bahkan dalam ajaran islam tindakan bom bunuh diri tidak dibenarkan. Pembunuhan terhadap diri sendiri merupakan pembunuhan yang diharamkan oleh Allah. Menurut pandangan akal, sewajarnya membunuh diri itu termasuk pembunuhan yang sangat kejam, karena manusia itu menurut sifatnya sendiri cinta kepada jiwa dan kehidupannya. Tidak patut ia melakukan penganiayaan, kemurkaan, dan penyiksaan terhadap diri sendiri. ${ }^{13}$

Dalilnya sudah Jelas di atas, disimpulkan bahwa perbuatan teroris itu sesuai dalam ajaran islam. Sangat tepat mereka bukanlah kelompok jihad, melainkan golongan teroris. ${ }^{14}$

\section{Terorisme Perspektif Hukum Pidana Islam}

Dalam hukum pidana Islam terorisme terbagi dalam dua golongan yaitu:

a. Jarimah Hirabah (Perampokan)

Menurut bahasa perampokan (hirabah) memiliki arti yaitu memerangi atau dalam kalimat haraballah artinya orang yang berbuat maksiat kepada Allah. ${ }^{15}$ Sedangkan menurut istilah, hirabah sama dengan qat'u tariq yakni sekelompok orang yang melakukan pertumpahan darah, keonaran, merampas kehormatan, harta, tatanan serta berbuat kerusakan di muka bumi.

Menurut Al-Qarafi dalam kitabnya Adz-Dzakhirah dan AlJawahir mengatakan bahwa:

${ }^{12}$.A.Z. Salim Marie., 80 Dosa Besar, Cet I, (Jakarta : Husaini Bandung, Desember 1991)., 66-67..

${ }^{13}$ Syech Mahmud Syaltut., Akidah dan Syari'ah Islam., (Jakarta : Bina Aksara, 1985)., 69.

${ }^{14} \mathrm{http}: / /$ abrahamik.wordpress.com/2010/02/12/teroris-dan-jihad-dalamislam/. (Diakses 3 Oktober 2019)

${ }^{15}$ M. Nurul Irfan, Hukum Pidana Islam, (Jakarta : Amzah, 2016), 88. 
Perampok ialah orang yang menghunus senjata untuk merampas, baik terjadi di kota-kota besar maupun di padang pasir, baik dilakukan oleh sekelompok orang ataupun tidak, pelakunya baik laki-laki maupun perempuan, tidak ditentukan dengan peralatan khusus seperti tambang, batu, mencekik dengan tangan atau dengan menggigit atau alat apa pun, tetap disebut sebagai perampok, walaupun tidak sampai membunuh jiwa, pokoknya setiap orang yang mengganggu keamanan di jalan dan menimbulkan rasa takut di jalan dan tempat-tempat keramaian di sebut al-muharib. ${ }^{16}$

Kata hirabah asal katanya yaitu kata harb yang berarti perang. Hirabah tergolong dosa besar. Di dalam Al-Qur'an Allah memberikan hukuman yang berat pada pelakunya, yang mana hukuman tersebut tidak dikenakan pada jarimah yang lain. ${ }^{17}$

Jarimah hirabah dapat terjadi dalam berbagai kasus: (1) orang yang berniat mengambil harta korban dengan terang-terangan dan juga mengancam korban, tapi si pelaku tersebut tidak jadi mengambil harta korban dan juga tidak membunuhnya; (2) orang yang berniat mengambil harta korban dengan terang-terangan namun tidak membunuh korbannya; (3) orang yang berniat merampok, lalu membunuh korban tersebut akan tetapi tidak mengambil hartanya; (4) orang yang berangkat dengan niat merampok kemudian mengambil hartanya dan korbannya dibunuh.

Ketentuan hukuman muharib, juga terjadi dialog antara Nabi dan Malaikat Jibril. Saat itu Rasulullah saw bertanya kepada Malaikat Jibril mengenai sanksi bagi orang yang melakukan jarimah hirabah. Lalu Malaikat Jibril menjawabnya ,"Barang siapa yang mengambil harta dan mengacau jalan, maka potong tangan sebab ia mencuri dan potong kakinya sebab ia mengacau, barang siapa yang membunuh bunuhlah, dan barang siapa membunuh dan mengacau perjalanan saliblah. Dan barang siapa yang membuat kekacauan tanpa mengambil harta dan membunuh, maka buanglah atau penjarakanlaah."

${ }^{16}$ Pandangan Al-Qarafi terhadap pengertian perampok di buku Fiqih Jinayah, yang ditulis oleh H. M. Nurul Irfan \& Masyrofah,...125. 1993)., 175

${ }^{17}$ Sayyid Sabiq., Fiqih Sunnah., Cet VI, (Bandung: Al-Ma'arif Bandung, 
b. Jarimah Al-Baghy (Pemberontakan)

Al-Baghyu (pemberontakan) artinya seseorang yang tidak taat kepada imamnya yang sah dengan tanpa alasan. Menurut Ulama Syafi'iyah yang dimaksud al baghyu (pemberontak) ialah orang-orang muslim yang menyalahkan imam dengan tidak taat kepadanya dan mau melepaskan diri dari imam yang sah atau menolak kewajibannya dengan adanya kekuatan, pendapat-pendapat, dan memiliki pemimpin yang lain. Sedang ulama madzhab Maliki berargumen, bahwa albaghyu adalah suatu penolakan untuk taat kepada imam yang sah dengan cara adanya kekuatan. Apabila para pemberontak tersebut melakukan tindakannya, maka pemerintah wajib memeranginya dengan ketentuan tersebut tindakan mereka yang ingin melawan pemerintah yang adil kepada rakyatnya, tindakan mereka yang dilakukan oleh sekelompok yang mempunyai kekuatan, tindakan mereka melawan penguasa disebabkan oleh perbedaan pendapat terkait dengan masalah politik, sehingga ingin memisahkan diri dari penguasa. Mereka dipimpin oleh satu komando yang menjadi sumber kekuatan moral bagi mereka saat melakukan tindakannya. ${ }^{18}$

Sebagian ulama telah memahami hukumnya bagi pemberontak yaitu hukumannya harus di bunuh. Dalam Al-Quran, memerangi para pemberontak ialah hukumnya wajib, karena hukumnya Allah harus ditegakkan, sebagaimana telah diterangkan dalam Q.S. Al-Hujurat ayat 9.

Lalu al-baghyu juga memiliki unsur-unsur yaitu:

1) Memberontak kepada Imam Negara yang sah dan berdaulat

Maksudnya ialah sebagai upaya untuk menghentikan jabatannya imam yang sah dalam suatu negara. Undang-undang tersebut tidak dipatuhi oleh para pemberontak dan mereka tidak mau melaksanakan kewajibannya sebagai warga negara.

2) Dilakukan secara demonstratif

Maksudnya adalah ada dukungan dari kekuatan bersenjata. Oleh karena itu menurut ulama fiqih, sikap sekedar penolakan imam yang diangkat melalui aklamasi, itu bukanlah al-baghyu.

${ }^{18}$ Muhammad Amin Suma, Dkk., Pidana Islam di Indonesia Peluang, Prospek, dan Tantangan, Cet I, (Pejaten Barat: Pustaka Firdaus., 2001), 60-61. 
3) Termasuk perbuatan Pidana

Maksudnya ialah suatu usaha menggulingkan pemerintah yang sah dengan membuat kekacauan di tempat umum. Jika perbuatan para pemberontak tidak mengarah pada tindakan penggulingan pemerintahan dan tidak berbuat jarimah (seperti merampas, membunuh, merampok, dan memperkosa), maka menurut para ulama fiqih itu tidak dikatakan al-baghyu. ${ }^{19}$

\section{E. Penutup}

Dari uraian di atas, maka dapat diambil kesimpulan sebagai bagian dalam penutup ini adalah terorisme adalah suatu tindakan yang membuat ketakutan dan kengerian di kalangan masyarakat dan mengancam keamanan negara. Dalam hukum pidana islam (fiqih jinayah), terorisme terbagi menjadi dua golongan yaitu al-hirabah dan al-baghyu. Golongan al-hirabah harus dipidana dengan pidana hukuman mati, disalib, potong tangan dan kakinya secara bersilang dan hukuman pengasingan. Sedang al-baghyu harus di perangi sampai mereka kembali kepada Allah. Terorisme tidak bisa dikaitkan dengan jihad. Mengapa? Karena jihad merupakan suatu tindakan untuk membela atau memperjuangkan agama-Nya Allah dengan tujuan yang mulia. Adapun terorisme merupakan suatu tindakan yang membuat kengerian terhadap orang-orang yang tidak berdosa untuk mencapai tujuan politiknya. Tindakan bunuh diri merupakan perbuatan yang di haramkan oleh Allah dalam islam yang mengakibatkan orang tersebut masuk ke dalam neraka. Dalam ajaran islam, tindakan tersebut tidak dibenarkan karena Allah sangat mencintai dan menyayangi setiap hamba yang memohon kepada-Nya.

\section{Referensi}

Al-Qur'an dan Terjemahannya (Mushaf Fatimah), Jakarta: PT. Insan Media Pustaka, 2012.

Abimanyu, Bambang, Teror Bom Di Indonesia, Jakarta : Grafindo Khazanah Ilmu, 2005.

\footnotetext{
${ }^{19}$ M. Nurul Irfan dan Masyrofah, Fiqh Jinayah, Cet II., (Jakarta : Amzah.,
} 2014), 68 
Amin Suma, Muhammad, dkk., Pidana Islam di Indonesia Peluang, Prospek, dan Tantangan, Cet I, Pejaten Barat: Pustaka Firdaus., 2001.

Chirzin, Muh., Reaktualisasi Jihad fi Sabilillah dalam Konteks Kekinian dan Keindonesiaan, Ulumuna, Volume X, Nomor 1 Januari-Juni 2006.

Ghony, Djunaidi, dan Fauzan Almanshur, Metodologi Penelitian Kualitatif, Yogyakarta : Ar-Ruzz Media, 2016.

Hanafi, Ahmad, Asas-Asas Hukum Pidana Islam, Cet. V, Jakarta : Bulan Bintang, 1993.

Hanif Hassan, Muhammad, Teroris Membajak Islam, Meluruskan Jihad Sesat Imam Samudra \& Kelompok Islam Radikal, Jakarta Selatan : Grafindo Khazanah Ilmu, 2007.

http://abrahamik.wordpress.com/2010/02/12/teroris-dan-jihad-dalamislam/. (Diakses 3 Oktober 2019)

http://rifakh.blogspot.com/2016/12/makalah-sebab-sebabterhapusnya-hukum.html. (Diakses 28 September 2019).

Irfan, M. Nurul, Hukum Pidana Islam, Jakarta : Amzah, 2016.

Irfan, M. Nurul, Masyrofah, Fiqh Jinayah, Cet II, Jakarta : Amzah., 2014.

Kartasapoetra, G., dan Hartini., Kamus Sosiologi dan Kependudukan, Cet II, Jakarta : Bumi Aksara, 2007.

Labay El-Sulthani, K.H. Mawardi, Umat Islam Siap Perang, Jakarta : Al Mawardi Prima, 2002.

luax-berjaya-blogspot.com/2011/10/kejahatan-terorisme.html. (Diakses 23 Juli 2018).

Mardenis, Pemberantasan Terorisme, Politik Internasional dan Politik Hukum Nasional Indonesia, Jakarta : Raja Grafindo Persada, 2011. 
Mardenis, Pemberantasan Terorisme, Politik Internasional dan Politik Hukum Nasional Indonesia, Cet I., Jakarta : Rajawali Pers, 2011.

Marie, A.Z. Salim, 80 Dosa Besar, Cet I, Jakarta : Husaini Bandung, Desember 1991.

Munajat, Makhrus, Hukum Pidana Islam di Indonesia, Cet I, Yogyakarta : Teras, 2009.

Prastowo, Andi, Metode Penelitian Kualitatif Dalam Perspektif Rancangan Penelitian, Jogjakarta : Ar-Ruzz Media, 2016.

Rohimin, Jihad, Makna dan Hikmah, Jakarta : Erlangga, 2006.

Sabiq, Sayyid, Fiqih Sunnah., Cet VI, Bandung: Al-Ma'arif Bandung, 1993.

Saidurrahman, Fiqh Jihad dan Terorisme (Perspektif Tokoh Ormas Islam Sumatera Utara), Jurnal Ilmu Syariah dan Hukum, Vol. 46 No. 1. Januari-Juni 2012.

Suma, Muh. Amin, dkk., Pidana Islam Di Indonesia Peluang, Prospek, dan Tantangan, Cet I, Pejaten Barat : Pustaka Firdaus, 2001.

Syaltut, Syech Mahmud, Akidah dan Syariah Islam, Jakarta : Bina Aksara, 1985.

Wahid, Abdul, Sunardi dan Muhammad Imam Sidik, Kejahatan Terorisme Perspektif Agama, HAM, dan Hukum, Cet I., Bandung: Refika Aditama, 2004.

* Mahasiwa dan dosen fakultas syariah IAIN Palu 